\title{
Changes in seed quality during fruit maturation of sweet pepper
}

\author{
Deborah de Souza Vidigal ${ }^{1}$, Denise Cunha Fernandes dos Santos Dias², Luiz Antônio dos \\ Santos Dias ${ }^{2}$, Fernando Luiz Finger ${ }^{2}$ \\ ${ }^{1} U F V$ - Programa de Pós-Graduação em Fitotecnia. \\ ${ }^{2} U F V$ - Depto. de Fitotecnia - 36570-000 - Viçosa, MG - Brasil. \\ *Corresponding author <dcdias@ufv.br> \\ Edited by: Edmilson José Ambrosano
}

\begin{abstract}
Studies regarding seed maturation are important to determine the ideal fruit development stage for harvesting in order to obtain high-quality seeds. Changes in sweet pepper (Capsicum annuum L.) seed quality were monitored during seed development in order to identify the stage of maximum quality of the seeds and the optimum harvest date. Fruits harvested from 20 to 75 days after anthesis (DAA) with step of five days were grouped according to maturity stage (green, yellow, red and intense red color outside). Before seed extraction, the fruit weigh, diameter and length were determined. Seed water content, seed dry weight, 1.000-seed weight, germination, first count, speed emergence index, seedling length, accelerated aging and electrical conductivity tests were performed. Mass maturity of the seeds was attained at $75 \mathrm{DAA}$, when seed water content was $47.3 \%$ and the fruits were red. Sweet pepper seeds with high germination and vigour should be harvested when fruits are completely red outside, at 75 DAA.
\end{abstract}

Keywords: Capsicum annuum L., maturity, harvest, vigour

\section{Introduction}

Production of high quality seeds depends upon the appropriate time of harvest. In general, seed crops should be harvest when seed quality is maximal. However, the stage during seed development at which seeds attain maximum quality is subject of some controversy. Seeds developed in fleshy-fruited species generally attain maximum germination and vigor at the end of the seed-filling period, when physiological maturity is reached (Welbaum, 1999). However, in some those species, maximum seed dry matter accumulation and seed quality do not coincide, such as pepper (Capsicum annuum L.)(Demir and Ellis, 1992b; Oliveira et al., 1999), melon (Cucumis melo L.) (Welbaum and Bradford, 1988) and tomato (Lycopersicon esculentum Mill.) (Kwon and Bradford, 1987; Berry and Bewley, 1991; Demir and Ellis, 1992a; Demir and Samit, 2001; Dias et al., 2006a). In tomato seeds, Kwon and Bradford (1987) found that maximum germination and vigor occurred 15 days after attainment of maximum dry mass. It was also verified by Demir and Ellis (1992a), to whom the highest germination percentage was obtained at $70 \mathrm{DAA}$, while the maximum dry matter content occurred at 50 DAA. Similar results were reported in pepper seeds, where maximum values of germination and dry matter was attained at $60 \mathrm{DAA}$ and 50 DAA, respectively (Oliveira et al., 1999).

In general, degenerative changes occur in the seeds once full physiological maturity has been attained (Harrington, 1972). Under field conditions, the transition from high quality to aged or even dead muskmelon seeds occurs swiftly over a matter of a few days (Welbaum, 1999). Then, the occurrence of maximum seed quality during development and its association with seed and fruit features are important factors to define the ideal harvest time. This study was done to verify the development stage when sweet pepper (Capsicum annuиm L.) seeds acquire maximum quality and to define the optimum harvest date.

\section{Materials and Methods}

Sweet pepper seeds (Amarela Comprida cultivar) were sown in the first week of January 2007, in four trays (90 cells per tray) containing a commercial substratum in Viçosa, MG, Brazil. The 40 day-old seedlings were transplanted to the field totaling approximately 300 seedlings. Plant spacing was 1.2 $\mathrm{m}$ between rows and $0.8 \mathrm{~m}$ between plants constituting 30 plants per plot. Before planting, fertilization was applied according to Ribeiro et al. (1999). The sprinkler irrigation was applied as required and plants were tutored using sticks. The maximum and minimum temperatures during the whole growing season recorded were 32 and $14{ }^{\circ} \mathrm{C}$, respectively.

Flowers were tagged at anthesis, and the fruits were harvested from 20 to 75 days after anthesis (DAA) with step of 5 days. Then, harvested fruits were classified according to the maturation stage based on fruits color on the outside, e.g. completely green (20 to $40 \mathrm{DAA}$ ); yellow (45 to $50 \mathrm{DAA}$ ), red (55 to $65 \mathrm{DAA}$ ) and intense red (70 to 75 DAA). Seeds were extracted manually, and a sample freshly extracted seeds was used to determine seed water content by drying for $24 \mathrm{~h}$ at $105 \pm 3{ }^{\circ} \mathrm{C}$ (Brasil, 1992). The remaining sample was then dried to $10 \%$ water content (fresh weight basis) at room temperature. The following parameters were performed:

Fruit weight - Thirty fruits from each harvest time were weighed individually $(0.0001 \mathrm{~g})$ and fruit weight was expressed as mean fruit weight ( $\mathrm{g}$ per fruit).

Fruit length and diameter - Thirty fruits from each harvest time were measured individually and the results were expressed as mean fruit length and diameter ( $\mathrm{mm}$ per fruit).

1,000 -seeds weight - eight replications of 100 seeds were weighed $(0.0001 \mathrm{~g})$ and 1,000 -seeds weight was done according procedures described by Seed Testing Rules (Brasil, 1992).

Sci. Agric. (Piracicaba, Braz.), v.68, n.5, p.535-539, September/October 2011 
Standard germination - four replicates of 50 seeds each were distributed over two sheets of paper towel moistened with $0.2 \% \mathrm{KNO}_{3}$ solution, in germination boxes $(110 \times$ $110 \times 40 \mathrm{~mm}$ ) and incubated at $25^{\circ} \mathrm{C}$ (Brasil, 1992). The normal seedlings percentage was determinated 10 -day and 17 day after seeding.

Seedling length - four replicates of 20 seeds each were distributed equidistant on the upper end of the paper towel in the germination boxes described previously. The boxes containing the seeds were placed inclined at an angle of about $45{ }^{\circ} \mathrm{C}$ to favour radicle vertical growth in the germinator at $25{ }^{\circ} \mathrm{C}$. The length ( $\mathrm{mm}$ per seedling) of the normal seedlings was measured 10 days after seeding.

Accelerated aging - the seeds were distributed on a wire mesh screen suspended over $40 \mathrm{~mL}$ of water inside a germination box (AOSA, 1983). Boxes were held in an incubator at $42 \pm 0.5^{\circ} \mathrm{C}$ for $96 \mathrm{~h}$ (Bhering et al., 2006), and then four replicates of 50 seeds each were tested for germination as described previously. The evaluation was done ten days after seeding and the mean normal seedling percentage was calculated.

Electrical conductivity - four replicates of 50 seeds each were weighed and then soaked in $50 \mathrm{~mL}$ distilled water and incubated for $24 \mathrm{~h}$ at $25{ }^{\circ} \mathrm{C}$ in the dark. The electrical conductivity of the soak solution was measured using a conductivity meter, and the results were expressed as mean $\mu \mathrm{S} \mathrm{cm}^{-1} \mathrm{~g}^{-1}$ seeds (ISTA, 1995).

Speed emergence index (SEI) - in a greenhouse, four replicates of 50 seeds each were planted 3-mm deep in a commercial planting substrate in plastic trays $(230 \times 160 \times 160$ $\mathrm{mm})$. Emerged seedlings were counted daily for 30 days and SEI was calculated, Equation 1 (Maguire, 1962).

$\mathrm{SEI}=\mathrm{E}_{1} / \mathrm{N}_{1}+\mathrm{E}_{2} / \mathrm{N}_{2}+\ldots+\mathrm{E}_{\mathrm{n}} / \mathrm{N}_{\mathrm{n}}$

where: $\mathrm{E}_{1}, \mathrm{E}_{2}, \mathrm{E}_{\mathrm{n}}=$ number of seedlings recorded on first, second and final count; $\mathrm{N}_{1}, \mathrm{~N}_{2}, \mathrm{~N}_{\mathrm{n}}=$ number of days from sowing to first, second and final count.

The study was done in the completely randomized design with four replications. The data obtained for each parameter were subjected to regression analysis using Statistical Analysis System (SAS Institute, 1989). Models were chosen based on the significance of the regression coefficient using the ' $\mathrm{t}$ ' test at a 0.05 and 0.01 probability level.

\section{Results and Discussion}

Fruit diameter (Figure 1 a), weight (Figure 1 b) and length (Figure $1 \mathrm{c}$ ) increased consistently until approximately between 40 and 45 DAA followed by slightly increase. At 65 DAA fruit weight was $45.52 \mathrm{mg}$ per fruit and at $75 \mathrm{DAA}$ was $45.53 \mathrm{mg}$ per fruit. In general, fruit size tend to stabilize or decrease at the end of the fructification process of indeterminate growth plant, as observed in tomato by Dias et al. (2006b). These authors found differences among tomato fruit weight according to fructification sequence in the plant, where fruits from $6^{\text {th }}$ trusses had lower weight than first-truss fruits.
The dry matter content of seeds (Figure 1d) increased with fruit age up to $75 \mathrm{DAA}$, when fruits were completely red. Therefore, mass maturity described by Ellis and Pieta Filho (1992) as the end of the seed-filling period occurred around 75 DAA. In pepper seeds, Demir and Ellis (1992b) found that the maximum dry matter content was obtained approximately at 50 DAA, while fruits were $50 \%$ red. In tomato seeds the maximum dry matter content was verified at $75 \mathrm{DAA}$, when the fruits were $90 \%$ red (Dias et al. 2006a). The weight of one thousand seeds was maximum at the end of the maturation process at 75 DAA (Figure 1e), near to the highest dry matter content value (Figure 1d). These findings are similar to those of Dias et al. (2006a) in which the highest values of 1,000 tomato seeds weight and dry matter content were attained at same time.

At $20 \mathrm{DAA}$, when the fruits were completely immature (green color outside), the seed water content was $91.8 \%$, decreasing to $49.1 \%$ at $55 \mathrm{DAA}$ (red fruits) attaining $47.3 \%$ at 75 DAA (Figure 1f). One the main characteristics of seed development in fleshy-fruited vegetables is that seed water content remains at values of about 35-40 \% within the fruit (Tekrony and Egli, 1997). Then, there was a steadily decline in the seed water content while the dry matter continued to accumulate and moisture content remained high even after maximum dry matter has been accumulated, as related in several species that produce seeds inside a flesh fruit (Demir and Ellis, 1992a, b; Bewley and Black, 1994; Demir et al., 2002; Dias et al., 2006a, c; Vidigal et al., 2006). In these species the accumulation of osmotic solutes, primarily sugars, creates a low water potential inside the fruit that maintains high seed water content, but below the threshold required for germination (Welbaum and Bradford, 1988).

Seed water content is not considered a good indicator of physiological maturity of the seeds, since can be affected by genotype and environmental conditions. This fact was demonstrated by Demir and Ellis (1992a) in experiments conducted in two subsequent years. These authors obtained different moisture content values for tomato seeds at physiological maturity, respectively $53 \%$ and $72 \%$ in 1989 and 1990. Similar results were found by Demir et al. (2002) in eggplant (Solanum melongena L.) seeds.

Seeds from fruits harvested between 20 and 40 DAA did not germinate (data was not included in Figure 2a). There was an increase in the germination percentage along maturation process, especially between 40 DAA and 55 DAA. Seed germination increased slightly up to the end of maturation when the maximum dry matter content of the seeds was achieved (75 DAA). Dias et al. (2006a) showed that higher germination percentage was obtained before the maximum dry matter content of the tomato seeds. Contrasting results regarding maximum seed quality occurrence during seed development have been showed. In tomato, maximum seed quality was attained more than 20 days after the maximum dry matter content (Demir and Ellis, 1992a). Similar results were found in eggplant (Demir et al., 2002) and pepper seeds (Oliveira et al., 1999; Demir and Ellis, 1992b). 

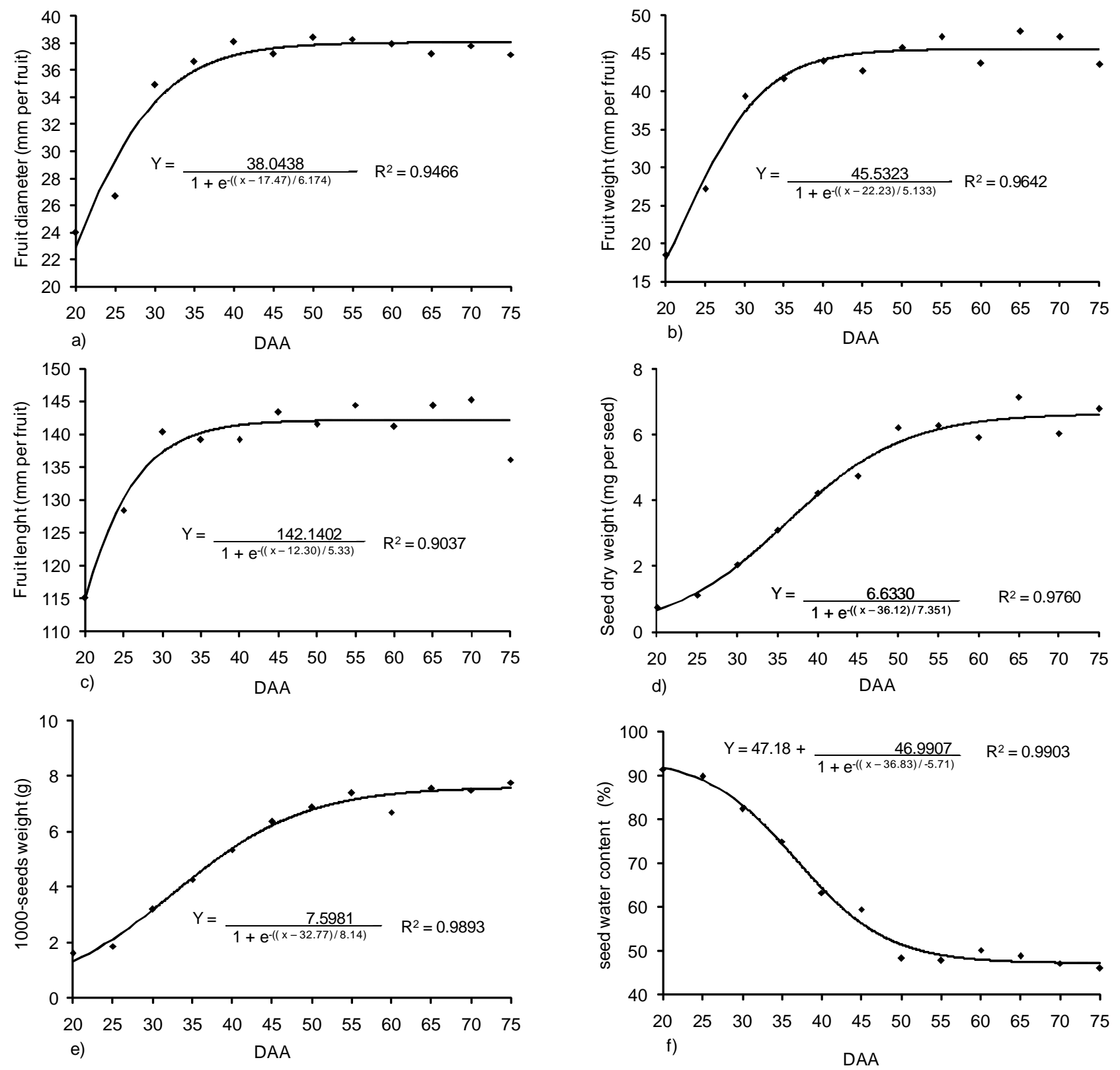

Figure 1 - Changes in fruit weight, diameter and length, seed dry weight, seed water content and 1000-seed weight during maturation of sweet pepper (DAA).

Seed vigor increased along maturation process, although there was small variation among vigor tests in relation to harvest time where seed vigor was maximum (Figures $2 \mathrm{~b}$ to 2e). In general, the maximum seed vigor was recorded approximately at $60 \mathrm{DAA}$ when fruits were red. High seed germination percentage was attained from 55 DAA increasing slowly until 75 DAA.

The highest electrical conductivity value was obtained at 20 DAA, declining gradually till 65 DAA (Figure $2 \mathrm{f}$ ). Thus maximum electrical conductivity coincided with the lowest germination percentage of the seeds, while lower conductivity values were recorded from 65 DAA until 75 DAA when seed vigor was high. These results suggest that there was an increase of cell mem- branes integrity and subsequent reduction of electrolytes leakage along seed development as reported by Demir and Ellis (1992a) and Dias et al. (2006b) in tomato. The final stage of the maturation process is marked by dehydration, in such a manner that during the reserve deposition phase, there is also accumulation of potentially protective molecules, especially lea (late embryogenesis accumulated) proteins and soluble sugars, such as sucrose, raffinose, and stachyose to prevent the membrane damage caused by water removal from the seed tissues (Bewley and Black, 1994).

Maximum seed quality can be determined by a combination of attributes as germination percentage and vigor. In general, the maximum germination and vigour of sweet pepper seeds was obtained approximately 75 DAA (Figure 

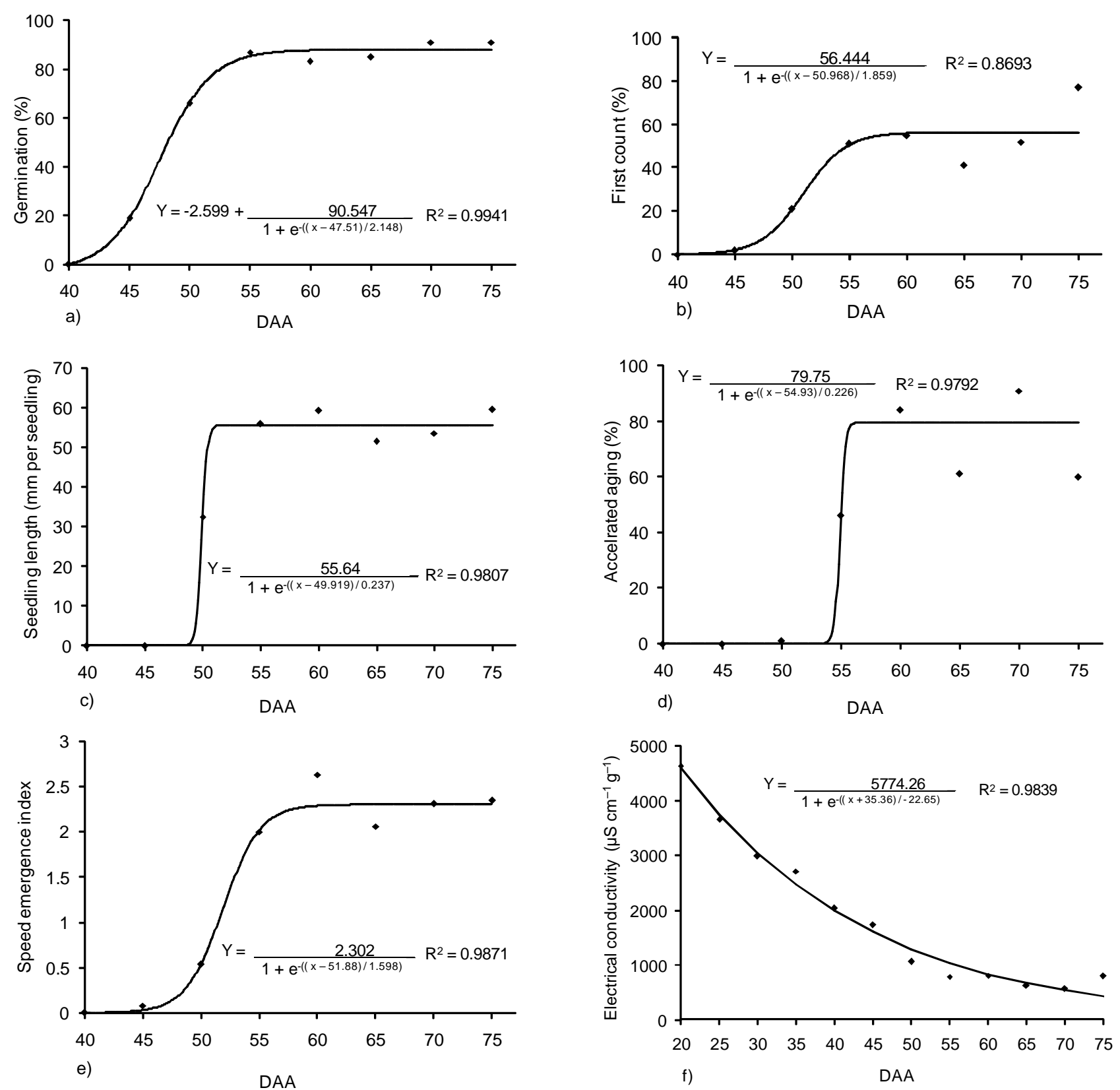

Figure 2 - Changes in germination percentage, first count, seedling length, accelerated aging, speed emergence index and electrical conductivity of sweet pepper seeds during maturation (DAA).

2), when the fruits had red color outside coinciding with mass maturity, represented by maximum dry matter content, which was attained at 75 DAA (Figure 1d). These results, therefore, are consistent with the hypothesis proposed by Harrington (1972) that seeds attain maximum quality at the end of the seed-filling period and thereafter viability and vigor decline. This hypothesis has also been supported by investigations in melon (Welbaum and Bradford, 1988) and watermelon seeds (Demir et al., 2004).

In conclusion, sweet pepper seeds of cv. 'Amarela Comprida' reach mass maturity at $75 \mathrm{DAA}$, when seed water content was $47.3 \%$ (Figure 1f) and the fruits were red. Sweet pepper seeds with high germination and vigour should be harvested when fruits are completely red outside, at 75 DAA.

\section{References}

Association of Official Seed Analysts [AOSA]. 1983. Seed Vigor Testing Handbook. East Lansing, MI, USA. (Contribution, 32). Berry, T.; Bewley, J.D. 1991. Seeds of tomato (Lycopersicon esculentum Mill.) which develop in a fully hydrated environment in the fruit switch from a developmental to a germinative mode whitout a requeriment for dessication. Planta 186: 27-34.

Bewley, J.D.; Black, M. 1994. Seed: Physiology of Development and Germination. 2ed. Plenum Press, New York, NY, USA. $445 \mathrm{p}$. 
Bhering, M.C.; Dias, D.C.F.S.; Vidigal, D.S.; Naveira, D.S.P. 2006. Accelerated ageing test in pepper seeds. Revista Brasileira de Sementes 28: 64-71. (in Portuguese, with abstract in English).

Brasil. Ministério da Agricultura. 1992. Rules for Seed Testing. SNDA/ DNDV/CLAV, Brasília, DF, Brazil. (in Portuguese).

Demir, I..; Mavi, K.; Ozcoban, M. 2004. Changes in germination and potential longevity of watermelon (Citrullus lanatus) seeds during development. New Zealand Journal of Crop and Horticultural Science 32:139-145.

Demir, I.; Mavi, K.; Sermenli, T.; Ozcoban, M. 2002. Seed development and maturation in Aubergine (Solanum melongena L.). Gartenbauwissenschaft 67: 148-154.

Demir, I.; Ellis, R.H. 1992a. Changes in seed quality during seed development and maturation in tomato. Seed Science Research 2: 81-87.

Demir, I.; Ellis, R.H. 1992b. Development of pepper (Capsicum annuum L.) seed quality. Annals of Applied Biology 121: 385-399.

Demir, I.; Samit, Y. 2001. Seed quality in relation to fruit maturation and seed dry weight during development in tomato. Seed Science and Technology 29: 453-462.

Dias, D.C.F.S.; Ribeiro, F.P.; Dias, L.A.S.; Silva, D.J.H.; Vidigal, D.S. $2006 a$. Maturation of tomato seeds in relation to fructification sequence in the plant. Revista Ceres 53: 446-456. (in Portuguese, with abstract in English).

Dias, D.C.F.S.; Ribeiro, F.P.; Dias, L.A.S.; Silva, D.J.H.; Vidigal, D.S. 2006b. Tomato seed quality harvested from different trusses. Seed Science and Technology 34:681-689.

Dias, D.C.F.S.; Ribeiro, F.P.; Dias, L.A.S.; Silva, D.J.H.; Vidigal, D.S. 2006c. Tomato seed quality in relation to fruit maturation and postharvest storage. Seed Science and Technology 34: 691-699.

Ellis, R.H.; Pieta Filho, C. 1992. Seed development and cereal seed longevity. Seed Science Research 2: 9-15.

Harrington, J.F. 1972. Seed storage longevity. p. 145-245. In: Kozlowsky, T.T., ed. Seed biology. Academic Press, New York, NY, USA.
International Seed Testing Association [ISTA]. 1995. Handbook of Vigour Test Methods. 3ed. Zürich, Switzerland.

Kwon, O.S.; Bradford, K.J. 1987. Tomato seed development and quality as influenced by preharvest treatment with ethephon. HortScience 22: 588-591.

Maguire, J.D. 1962. Speeds of germination-aid selection and evaluation for seedling emergence and vigor. Crop Science 2: 176-177.

Oliveira, A.P.; Gonçalves, C.P.; Bruno, R.L.A.; Alves, E.U. 1999. Physiological maturation of pepper seeds in relation to fruit age after anthesis. Revista Brasileira de Sementes 21: 88-94. (in Portuguese, with abstract in English).

Ribeiro, A.C.; Guimarães, P.T.G.; Alvarez, V.H. 1999. Recomendation for the use of fertilizers in Minas Gerais: 5th approach. CFSEMG, Viçosa, MG, Brazil. (in Portuguese).

SAS Institute. 1989. Statistical User's Guide: Version 6. 4ed. SAS Institute.,CARY, NC, USA.

Tekrony, D.M.; Egli, D.B. 1997. Acumulation of seed vigour during development and maturation. p. 369-384. In: Ellis, R.H.; Black, M.; Murdock, A.J.; Hong, T.H., eds. Basic and applied aspects of seed biology. Kluwer Academic, Boston, MA, USA.

Vidigal, D.S.; Dias, D.C.F.S.; Naveira, D.S.P.; Rocha, F.B.; Bhering, M.C. 2006. Physiological quality of tomato seeds in relation to fruit age and post-harvest storage. Revista Brasileira de Sementes 28: 87-93. (in Portuguese, with abstract in English).

Welbaum, G.E. 1999. Cucurbit seed development and production. Horticulture Technology 9: 341-348.

Welbaum, G.E; Bradford, K.J. 1988. Water relations of seeds development and germination in muskmelon (Cucumis melo L.). I. Water relations of seeds and fruit development. Plant Physiology 86: 406-411.

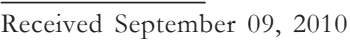

Accepted November 10, 2010 